\title{
The occurrence of a titanium dioxide/ (.) CrossMark silica white pigment on wooden Andean qeros: a cultural and chronological marker
}

\author{
Ellen Howe ${ }^{1 *} \mathbb{D}$, Emily Kaplan², Richard Newman ${ }^{3}$, James H. Frantz ${ }^{1}$, Ellen Pearlstein ${ }^{4}$, Judith Levinson ${ }^{5}$ \\ and Odile Madden ${ }^{6}$
}

\begin{abstract}
A white pigment found on a sub-set of polychromed wooden Andean ritual drinking cups called qeros has been characterized by X-ray diffraction, X-ray fluorescence spectroscopy and Raman spectroscopy as consisting principally of cristobalite $\left(\mathrm{SiO}_{2}\right)$, anatase $\left(\mathrm{TiO}_{2}\right)$, and a-quartz $\left(\mathrm{SiO}_{2}\right)$. This unexpected assemblage of minerals is like that reportedly found in an exposed titanium ore body in southern Peru, an area once part of the Inka Empire. The ore is a close match in color and composition to the white pigment found on the qeros and offers a possible candidate for the geological source of this material. The temporal horizon for the use of this pigment appears to be ca. 1532-1570, correlating with what we refer to here as the Transitional Inka/Early Colonial period, although production of polychromed qeros may have begun before this time and certainly continued well into the eighteenth century or later. Not long after the arrival of the Spanish, this titanium dioxide/silica pigment was replaced by lead white, a result of Spanish influence. We suggest that white pigments on qeros offer material evidence for establishing a chronology for these ritual vessels and that the titanium dioxide/silica pigment on this group of qeros constitutes a previously unidentified, naturally occurring white pigment indigenous to the southern Andes, the first use of which probably dates to the PreColumbian period.
\end{abstract}

Keywords: XRD, XRF, Raman spectroscopy, Qero, Colonial, Andes, Inka, Titanium dioxide, Silica, Cristobalite, Anatase, AMS radiocarbon dating, Plant resin, Elaeagia

\section{Introduction}

Ritual drinking vessels called qeros (a Quechua word, sometimes spelled q'iru, kero or quero) have been manufactured in the Andean region for millennia. Still used today, qeros are a recognized symbol of both the Inka Empire (1438-1532 CE) and the traditions preserved by descendants of the Inka [1]. Traditionally, qeros have been made from a variety of materials, notably gold and silver as well as wood, ceramic, gourd, and stone, always in pairs, to express reciprocal social, political and religious relationships [2, 3]. Early chroniclers, including Betanzos, Guaman Poma, and Cobo, described the important role

\footnotetext{
*Correspondence: ellen.howe@metmuseum.org

${ }^{1}$ Metropolitan Museum of Art, 1000 Fifth Avenue, New York, NY 10028, USA

Full list of author information is available at the end of the article
}

of qeros and drinking in Inka ritual [4-6]. Inka wooden qeros were typically decorated with incised geometric designs without polychromy. After the Spanish invasion in 1532, Andean artists continued to produce qeros for native use, but mostly in wood as the use of gold and silver was restricted by the Spanish. Qeros from the era following the Spanish invasion and continuing through Peruvian independence in 1821 are usually referred to as "colonial" and are most often made of polychromed wood. Terminology for the colonial period varies; here we refer to the years after the arrival of the Spanish until the consolidation of Spanish power under Viceroy Francisco Toledo in 1570 as "Transitional Inka/Early Colonial" [7]. This appears to be the approximate temporal period for the use of the titanium dioxide/silica pigment discussed in the present article. In general, colonial qeros are decorated with an intricate polychrome technique consisting 
of pigments mixed with resin from the plant genus Elaeagia, sometimes known as mopa mopa [8]. Such qeros are often referred to as "painted", although strictly speaking the resin/pigment was not applied as a paint by brush, but rather was either inlaid into carved recesses in the wood or applied directly onto the wood's outer surface [8-10]. Incised and polychromed geometric forms called tocapu, characteristic of Inka iconography, were often included on the decorated surface, providing a link and symbolic reference to the Inka past and cultural practices. It is still unclear whether the polychrome technique pre-dates the arrival of the Spanish [8]. However, there is no question that the early imagery became a source of concern for the Spanish, as sixteenth and seventeenth century sermons and proclamations declared the indigenous imagery found on the earliest polychromed qeros to be idolatrous and subject to extirpation [11-14].

Some surviving Inka wooden qeros without polychromy have archaeological provenience [2,3], but we know of only three reliably excavated wooden qeros bearing polychrome decoration. Two of these are a pair excavated from an Inka tomb at Ollantaytambo, near Cusco, and dated stratigraphically to 1537-1539 CE [15], just a few years after the fabled 1532 encounter between the Inka emperor, Atahualpa, and the Spanish "conquistador", Fernando Pizarro. The third, excavated by Colleen Zori in 2011 at the site of Moqi, Loqumba Valley, Peru, can be dated to the Transitional Inka/Early Colonial period or to the preceding Late Horizon/Inka period (1476-1534 CE) (Colleen Zori, personal communications 2013). In general, extant colonial qeros are without reliable history, having been passed down as heirlooms and collected for the art market. Qeros dated stylistically $[2,3]$ to the Transitional Inka/Early Colonial period typically display a limited palette with few mixed colorants and sparse iconographic elements composed mostly of flora, fauna and geometric designs. Human figures are rare on qeros from this period, whereas the surfaces of later colonial examples are nearly completely covered with designs in a narrative style that includes numerous human figures in both Andean and European clothing and a greatly expanded palette in both pigment type and application technique (Fig. 1). Changes in qero materials and iconography were not linear, however, and likely overlapped to some degree. For the present study, one of the two qeros excavated at Ollantaytambo was generously made available for analysis by the Museo Inka in Peru and provides an important reference point for our chronological interpretation. This study focuses on white pigments from a group of twelve qeros, including the excavated example from Ollantaytambo (here identified as Museo Inka 230), plus eleven others attributed by style to the Transitional Inka/Early Colonial period and, for comparison,

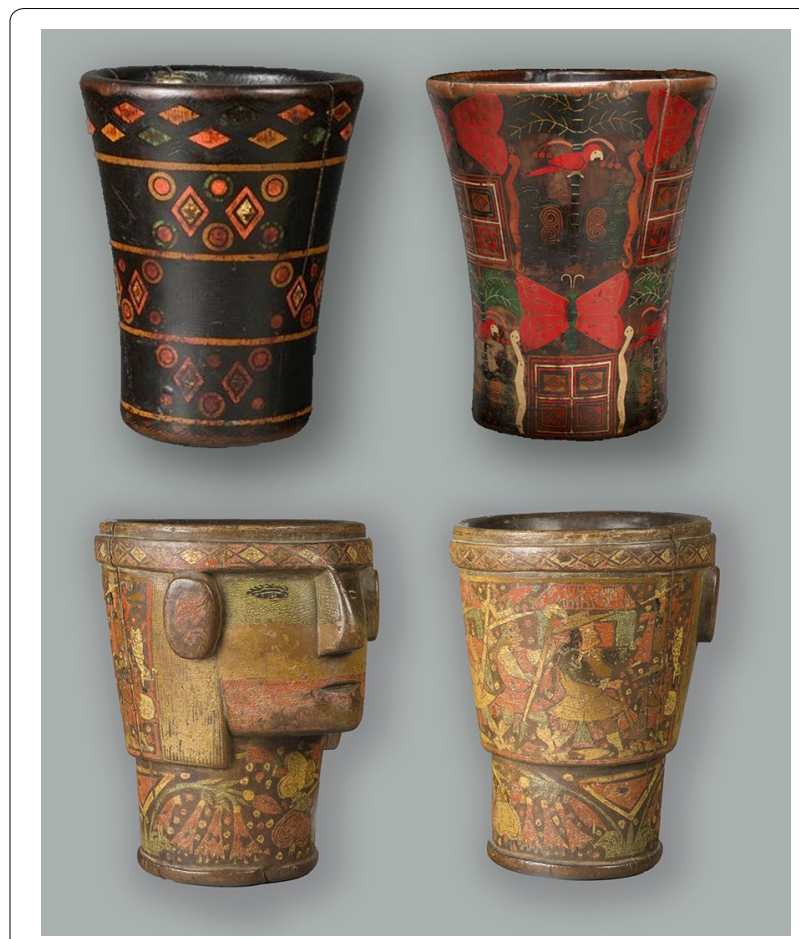

Fig. 1 Top: two Transitional Inka/Early Colonial qeros, MMA 1994.35.12 (left) and NMAI 15/2412 (right). Bottom: later colonial qero, MMA 1994.35.26 (left and right)

four qeros stylistically conforming to the later colonial period. These sixteen qeros are held at The Metropolitan Museum of Art (MMA), the Smithsonian National Museum of the American Indian (NMAI), the American Museum of Natural History (AMNH), the Museo Inka in Cuzco, Peru, and in one private collection. The qeros are of similar size, ranging in height between approximately 17 and $23 \mathrm{~cm}$. A summary listing of the group is given in Table 1, and images are shown in Additional file 1.

\section{Background of the qero research project}

The work reported here is part of a larger technical study begun in 1994 of 150 polychromed wooden qeros housed in the three US museums noted above and the Brooklyn Museum [9, 10, 16-18]. The study was designed to systematically characterize the materials and technology of a representative group of polychromed qeros, as well as to determine usage, indigenous repairs, and later restorations made by collectors. In consultation with curators, archaeologists, and art historians, the project has built on extensive ethnohistorical and art historical research [2, 3, 19], with a focus on the cultural dynamics of the transition between the Inka and colonial periods. This transition was culturally tumultuous and was accompanied by both persistence and change, not only in qero style and iconography, but also in pigment sources and selection. 
Table 1 Qeros investigated in this study

\begin{tabular}{lll}
\hline Owner/qero ID & Stylistic period & Provenience \\
\hline AMNH B1847 & Transitional Inka/Early Colonial & Unknown \\
Private collection 1 & Transitional Inka/Early Colonial & Unknown \\
Private collection 2 & Transitional Inka/Early Colonial & Unknown \\
MMA 1994.35.12 & Transitional Inka/Early Colonial & Unknown \\
MMA 1994.35.14 & Transitional Inka/Early Colonial & Unknown \\
Museo Inka 230 & Transitional Inka/Early Colonial & Excavated at \\
& & Ollantay- \\
NMAl 15/2412 & Transitional Inka/Early Colonial & Unknown \\
NMAI 15/2413 & Transitional Inka/Early Colonial & Unknown \\
NMAI 21/7453 & Transitional Inka/Early Colonial & Unknown \\
NMAI 10/5860 & Transitional Inka/Early Colonial & Unknown \\
NMAI 20/0236 & Transitional Inka/Early Colonial & Unknown \\
NMAI 25/1492 & Transitional Inka/Early Colonial & Unknown \\
MMA 1994.35.13 & Colonial & Unknown \\
MMA 1994.35.17 & Colonial & Unknown \\
MMA 1994.35.26 & Colonial & Unknown \\
Private collection 3 & Colonial & Unknown \\
\hline
\end{tabular}

\section{Pigments used for qero decoration}

A variety of organic and inorganic pigments have been previously identified on the corpus of 150 polychromed qeros referred to above, the style-based dates of which range from the late Inka period to around 1821, when Peru gained independence from Spain [3]. The nonwhite pigments found include orpiment, pararealgar, cinnabar, copper-based pigments, carbon black, earth pigments, and the organic dyestuffs cochineal and indigo. These materials are known to occur naturally in the Andes or to have been manufactured and used during the pre-Columbian and later periods as mineral pigments applied to wood and other substrates or as textile dyestuffs [20-24]. White pigments have received lesser attention. On Andean easel and wall paintings from colonial times, the predominant variety has generally been found to be lead white, consisting of basic lead carbonate $\left(2 \mathrm{PbCO}_{3} \cdot \mathrm{Pb}(\mathrm{OH})_{2}\right)$ often mixed with neutral lead carbonate $\left(\mathrm{PbCO}_{3}\right)$ [23], while published analyses of occurrences on Inka and pre-Inka painted surfaces most often describe calcium-based minerals, such as calcite, gypsum and apatite [25-28]. Occasional instances of early white pigments bearing $\mathrm{Ti}$ and/or Si have been reported, most often as clay-based minerals with quartz and/or titanium dioxide as minor constituents [25, 26, $29,30]$. On the qeros that we have studied and that can be stylistically dated to colonial times, we have found the white pigment to be exclusively lead white. However, on earlier examples, we have found the white pigment to be a material rich in $\mathrm{Ti}$ and $\mathrm{Si}$ with little evidence of clay; this pigment is the subject of the present paper. We discovered it during our early work on the qero project and outlined it briefly in a previous communication [16]. This material occurs on only twelve qeros that we have examined to date, including the excavated example from Ollantaytambo, here identified as Museo Inka 230, and appears to represent the white pigment and binder used on the earliest polychromed qeros. We will argue that the materials and technology of this pigment likely pre-date Spanish influence. We also describe here a geological anomaly known as the "Giacomo Deposit" and situated near the modern city of Tacna in southern Peru that may provide a plausible source for this pigment. This mineral deposit was being offered for exploitation as a commercial mine for titanium dioxide and silica in 2009, and several websites describing it remain as of 2018 [31-33].

\section{Experimental}

The approach used in the present study was based on a non-invasive analysis of white and light-colored pigments on the sixteen qeros listed in Table 1 using openarchitecture X-ray fluorescence spectroscopy (XRF), followed by structural analysis of samples using X-ray microdiffraction (XRD) and, for a sub-set of seven members of the group, Raman spectroscopy. Scanning electron microscopy combined with energy-dispersive X-ray spectrometry (SEM/EDS) was used in one instance to characterize sample morphology. This approach was designed to build upon data from the earlier survey and upon evidence provided by extensive conservation examinations that ruled out the presence of restoration in the areas sampled [10]. In addition to the pigments from the twelve qeros stylistically attributed to the Transitional Inka/Early Colonial period and the four examples from the later colonial period listed in Table 1, we also analyzed samples of ore from the "Giacomo Deposit" in Peru referred to above, as well as several synthetic titanium dioxide/silica mixtures. The analytical approach was also designed to ensure that the mineral assignments based on XRD and Raman analysis were supported by major elemental compositions obtained by XRF, as well as to investigate whether the correlation between the results of these methods was sufficient to permit rapid and accurate mineral characterization of other white-pigmented areas based on non-destructive XRF analysis alone. To support the chronological interpretation of the pigment data, samples of wood from two of the qeros were submitted for radiocarbon age determination.

\section{X-ray diffraction (XRD)}

Samples removed from the sixteen qeros listed in Table 1 were analyzed by X-ray microdiffraction using a Rigaku Dmax/Rapid instrument. The analyses were conducted 
using $\mathrm{Cu} \mathrm{K} \alpha$ radiation, an $800 \mu \mathrm{m}$ collimator, and a graphite monochromator on the incident beam. Each specimen was mounted on a glass fiber with Ambroid nitrocellulose binder and oscillated about two axes of the goniometer for exposure times between 10 and $16 \mathrm{~min}$. These were found sufficient to yield mostly well-defined patterns between $5^{\circ}$ and $90^{\circ} 2 \theta$. The "Giacomo Deposit" ore and comparative synthetic mixtures of cristobalite, anatase, quartz, and rutile were unconstrained by sample size and were analyzed as pressed powders by X-ray diffraction using a Philips PW3020 open-architecture diffractometer with $\mathrm{Cu} \mathrm{K \alpha}$ radiation. This approach was designed to provide an improved quantitative estimate of mineral components in the ore. Scans were performed between $5^{\circ}$ and $90^{\circ} 2 \theta$ as step scans at a step size of $0.04^{\circ}$ and a scan rate of $1.2^{\circ} / \mathrm{min}$ with a graphite focusing monochromator on the diffracted beam. All diffraction patterns were interpreted using Jade 9.0 from MDI Inc. and the current release of the ICDD PDF-4+ database.

\section{X-ray fluorescence spectroscopy (XRF)}

The non-invasive XRF analyses were carried out with two instruments according to the institutional location of the objects involved. Pigments on the qeros in the collection of the NMAI were analyzed with a portable Niton XL3t unit equipped with a Rh-target X-ray tube operated at $50 \mathrm{kV}$ with an unfiltered beam approximately $1 \mathrm{~cm}$ in diameter. All other XRF analyses were conducted at the MMA with a Bruker Artax 400 instrument equipped with a Rh-target X-ray tube, laser range finder, and $0.65 \mathrm{~mm}$ collimator, enabling the analysis of individual design elements on the qeros without significant interference from adjacent areas. Spectra were acquired from each location at $50 \mathrm{kV}$ and at $10 \mathrm{kV}$, respectively, the latter analyses being performed with a helium flush to facilitate detection of lower atomic number elements by minimizing absorption of low-energy characteristic X-rays by the air path of the open-architecture configuration.

\section{Raman spectroscopy}

Samples of white pigmented resin removed from seven qeros listed in Table 1 as stylistically belonging to the Transitional Inka/Early Colonial period and from one qero attributed to the later colonial period, but not included in Table 1, were analyzed by Raman spectroscopy at the Smithsonian Museum Conservation Institute and compared to spectra acquired from the "Giacomo Deposit" ore, Elaeagia resin and reference samples of anatase, rutile, and brookite from the collection of the Smithsonian National Museum of Natural History Division of Mineralogy. The spectra were collected with a NXR FT-Raman module coupled to a 6500 FTIR spectrometer (Thermo Electron Corporation, Madison,
WI, USA). The Raman module was equipped with a continuous wave $\mathrm{Nd}: \mathrm{YVO}_{4}$ excitation laser (1064 nm), liquid nitrogen-cooled germanium and thermoelectrically-cooled InGaAs detectors, and a $\mathrm{CaF}_{2}$ beamsplitter. Laser fluence was kept low to avoid damaging the heat-sensitive samples and varied between samples over a $15-1530 \mathrm{~W} / \mathrm{cm}^{2}$ range. The spectra were very noisy and fluorescent, and the Raman signal was enhanced by co-adding large numbers of scans $(2752-48,000)$ at 4 or $8 \mathrm{~cm}^{-1}$ spectral resolution. Spectra of the reference minerals and the "Giacomo Deposit" ore were obtained with a Thermo Almega dispersive Raman spectrometer at 532 and $780 \mathrm{~nm}$ excitations. The spectrometer incorporated CCD detection and an optical microscope. Spectra were collected with a $3.9 \mathrm{~cm}^{-1}$ spectral resolution and an analytical spot size of $3.1 \mu \mathrm{m}$.

\section{SEM/EDS}

A sample of white pigment from a Transitional Inka/ Early Colonial qero listed in Table 1 (MMA 1994.35.12) was placed on a polished carbon stub and treated dropwise with acetone and methylene chloride to liberate and disperse the particulate material from the binding medium. The sample thus treated was gold coated and examined in a Leo $1455 \mathrm{VP}$ variable-pressure scanning electron microscope at an operating voltage of $20 \mathrm{kV}$. Secondary-electron images were acquired at an average working distance of $5 \mathrm{~mm}$. EDS analyses were carried out on selected grains.

\section{Radiocarbon age determinations}

Samples of wood from two Transitional Inka/Early Colonial qeros listed in Table 1 (MMA 1994.35.12 and MMA 1994.35.14) were taken for radiocarbon age determination. The samples were removed as drillings from the underside of the qeros after disposal of approximately the first $2 \mathrm{~mm}$ of material to reduce possible contamination by adventitious hydrocarbons and other recent material. The recovered samples, weighing approximately $35 \mathrm{mg}$ each, were submitted to the NSF-Arizona AMS Laboratory at the University of Arizona for preparation and age determination by accelerator mass spectrometry (AMS).

\section{Results \\ XRD and XRF}

$\mathrm{X}$-ray microdiffraction analysis of inlay samples of white pigment obtained from the twelve qeros listed in Table 1 as stylistically conforming to the Transitional Inka/ Early Colonial period yielded mostly well-defined patterns with numerous lines in the front-reflection region. Unrestricted searches of the ICDD PDF-4+ database resolved each of these patterns with a high level of confidence as representing a mixture of minerals consisting 
predominantly of cristobalite, anatase, and $\alpha$-quartz, often with minor amounts of what were plausibly assigned as rutile, wollastonite and other minerals based on the occurrence of weak lines at the strongest peak positions for these phases. The patterns for samples of pink pigment found on two of the twelve qeros (Private Collection 2 and NMAI 10/5860) were resolved as representing cinnabar, cristobalite, anatase, and $\alpha$-quartz, while the pattern for a pink pigment from another qero (NMAI 15/2413) was determined to represent cinnabar, gypsum and anhydrite, suggesting that the titanium dioxide/silica pigment was used occasionally, but not always, in lieu of other white pigments in intentional color mixtures. These assignments are consistent with the XRF spectra obtained either directly from the same samples analyzed by XRD or from their associated sites on the objects themselves. Except for the detection limits imposed by the spectrometer used for samples analyzed at NMAI, the spectra for the white pigments are dominated by the K-lines of $\mathrm{Si}$ and Ti. Although the microdiffraction analyses were necessarily performed on unoriented samples, the near absence of peaks at the most common basal plane spacings of clay minerals, together with the overall strength of the pattern intensities associated with the silica and titanium dioxide phases cited above, suggest that any clay minerals are minor constituents. Additionally, the XRF spectra obtained from samples analyzed at the MMA with low excitation voltages and helium flush show only very weak $\mathrm{Al}$ lines in relation to those from $\mathrm{Si}$ and $\mathrm{Ti}$ as shown in Fig. 2 .
The diffraction patterns of the white pigments based on cristobalite and anatase from three qeros belonging to this group are compared graphically in Fig. 3. While the relative intensities between the several phases identified show some variation, the principal line positions are consistent throughout the patterns. In each case, the three principal phases account for more than $95 \%$ of the overall pattern intensity. These facts, together with the unusual context of the identified phases, suggest a common source material. The samples of white pigment from the four qeros attributed stylistically to the later colonial period yielded XRF spectra dominated by the L-lines of $\mathrm{Pb}$ and diffraction patterns that were explicitly resolved as representing mixtures of cerussite and hydrocerussite. A summary of the XRD and XRF analyses is presented in Table 2, while a selection of the diffraction pattern listings and their graphical integrations are given in Additional file 2 .

\section{Raman spectroscopy}

The anatase polymorph of titanium dioxide is characterized by a very strong Raman peak at $144 \mathrm{~cm}^{-1}$ and a series of three smaller peaks at 395,510 , and $634 \mathrm{~cm}^{-1}$. The FTRaman spectra of seven Transitional Inka/Early Colonial period qero samples include some combination of these peaks and no features of cerussite or hydrocerussite (Table 2, Fig. 4, Additional file 3). Five samples exhibit all four peaks, and two show a very clear peak at $144 \mathrm{~cm}^{-1}$ and a much weaker signal near the $634 \mathrm{~cm}^{-1}$ band. These spectra are consistent with the corresponding XRD

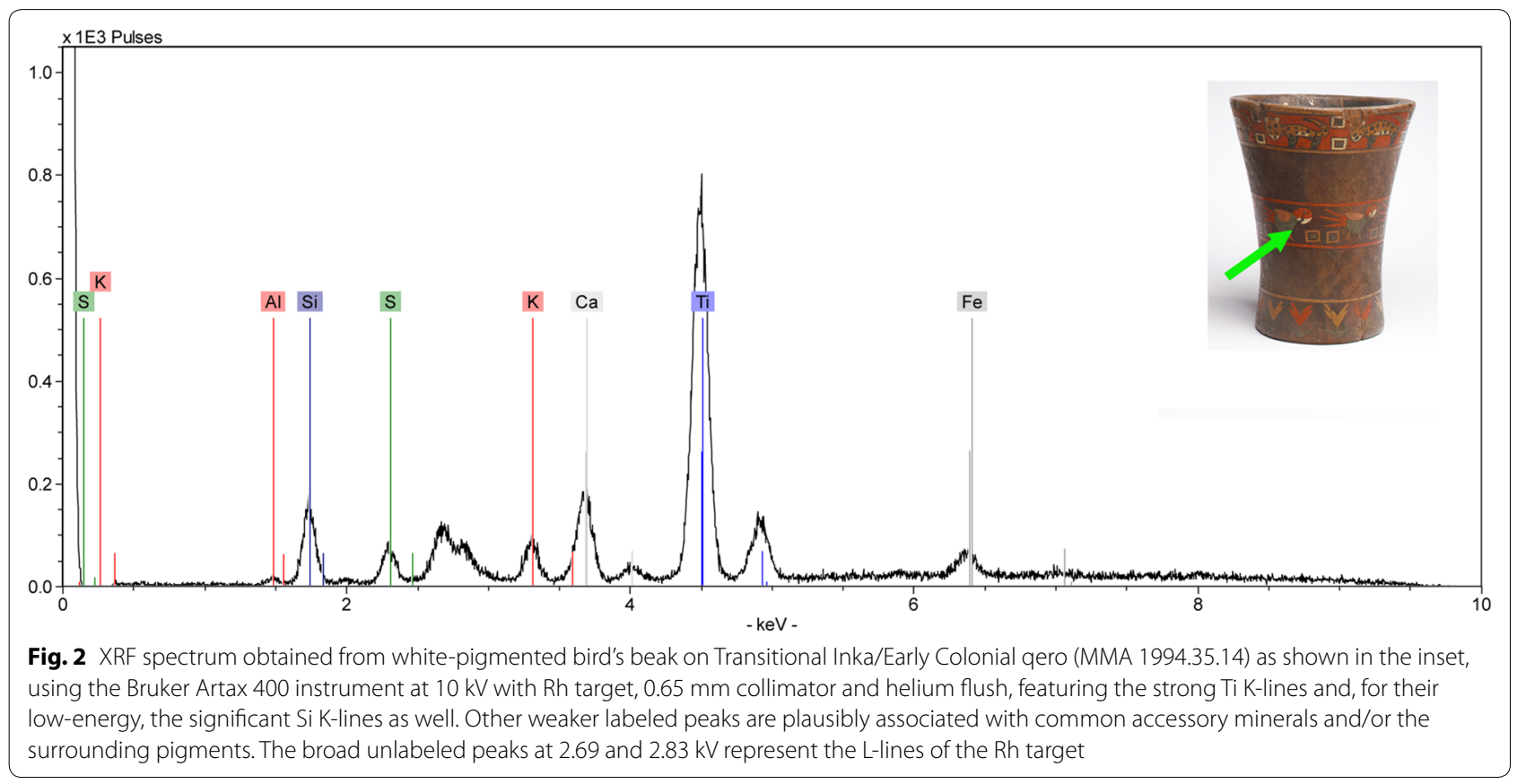




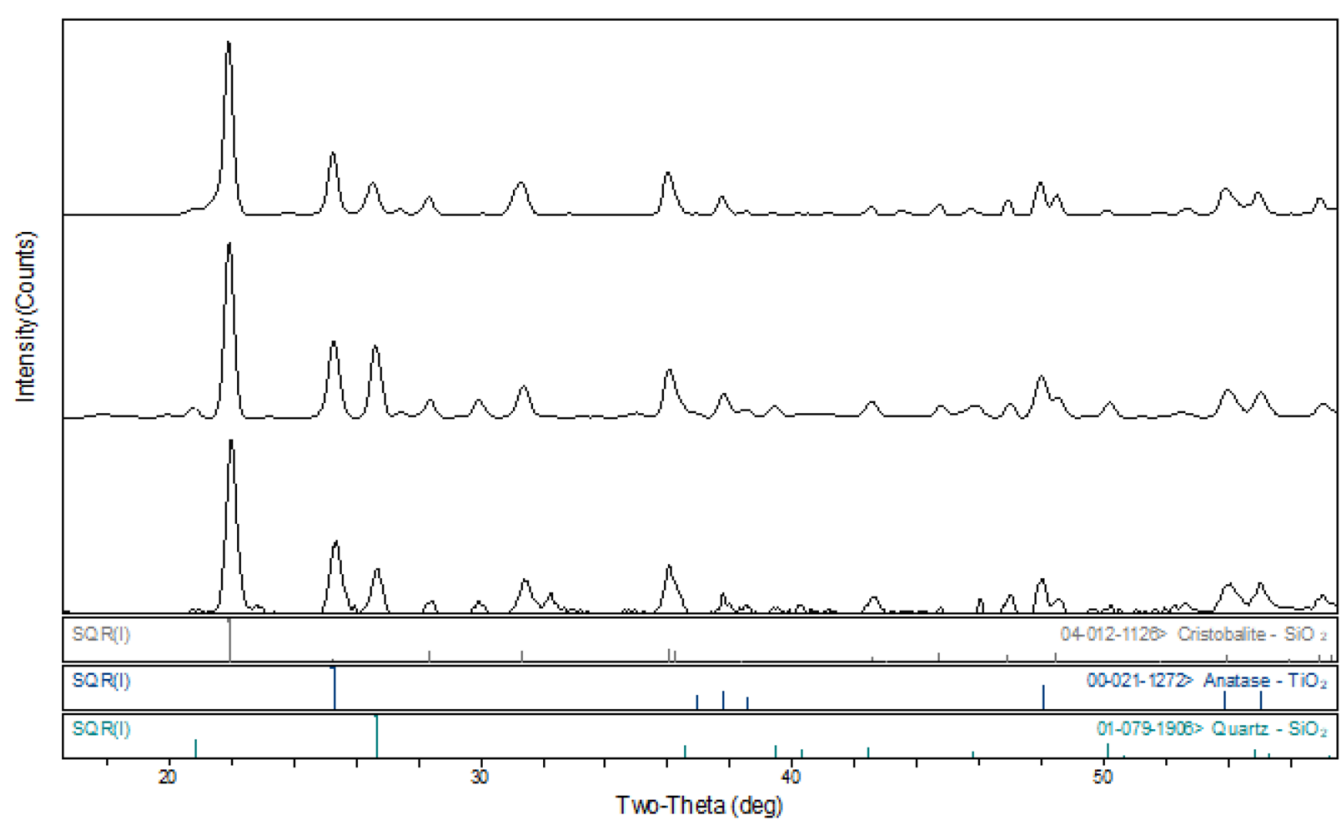

Fig. 3 XRD patterns of white pigments from three Transitional Inka/Early Colonial geros as integrated from the microdiffraction images (top: Museo Inka 230; middle: NMAI 20/0236; bottom: AMNH B1847). Ribbon bar intensities of PDF patterns shown as square root of relative value for legibility

Table 2 Summary of XRD, XRF, and Raman results of pigment analyses

\begin{tabular}{|c|c|c|c|c|c|}
\hline Owner/qero ID & Stylistic period & Color & Principal phases (XRD) & $\begin{array}{l}\text { Principal } \\
\text { elements (XRF) }\end{array}$ & Raman peaks \\
\hline AMNH B1847 & TI/EC & White & Cristobalite, anatase, a-quartz & $\mathrm{Si}, \mathrm{Ti}$ & $633,518,391_{w^{\prime}} 144$ \\
\hline Private collection 1 & TI/EC & White & Cristobalite, anatase, a-quartz & $\mathrm{Si}, \mathrm{Ti}$ & NA \\
\hline Private collection 2 & $\mathrm{TI} / \mathrm{EC}$ & Pink & Cinnabar, cristobalite, anatase, a-quartz & $\mathrm{Hg}, \mathrm{S}, \mathrm{Si}, \mathrm{Ti}$ & NA \\
\hline MMA 1994.35.12 & $\mathrm{TI} / \mathrm{EC}$ & White & Cristobalite, anatase, a-quartz & $\mathrm{Si}, \mathrm{Ti}$ & NA \\
\hline MMA 1994.35.14 & $\mathrm{TI} / \mathrm{EC}$ & White & Cristobalite, anatase, a-quartz & $\mathrm{Si}, \mathrm{Ti}$ & NA \\
\hline Museo Inka 230 & $\mathrm{TI} / \mathrm{EC}$ & White & Cristobalite, anatase, a-quartz & $\mathrm{Si}, \mathrm{Ti}$ & NA \\
\hline NMAI 15/2412 & TI/EC & White & Cristobalite, anatase, a-quartz & $\mathrm{Ti}$ & 638,145 \\
\hline NMAI 15/2413 & TI/EC & White & Cristobalite, anatase, a-quartz & $\mathrm{Ti}$ & $637,516,397,146$ \\
\hline NMAI 15/2413 & $\mathrm{TI} / \mathrm{EC}$ & Pink & Cinnabar, gypsum, anhydrite & $\mathrm{Hg}, \mathrm{S}, \mathrm{Ca}$ & NA \\
\hline NMAI 21/7453 & TI/EC & White & Cristobalite, anatase, a-quartz & $\mathrm{Ti}$ & $634,518_{w^{\prime}} 391_{w^{\prime}} 144$ \\
\hline NMAI 10/5860 & TI/EC & White & Cristobalite, anatase, a-quartz & $\mathrm{Ti}$ & $635,507_{w^{\prime}} 384_{w^{\prime}} 144$ \\
\hline NMAI 10/5860 & TI/EC & Pink & Cinnabar, cristobalite, anatase, a-quartz & $\mathrm{Hg}, \mathrm{Ti}$ & NA \\
\hline NMAI 20/0236 & $\mathrm{TI} / \mathrm{EC}$ & White & Cristobalite, anatase, a-quartz & $\mathrm{Ti}$ & 642,144 \\
\hline NMAI 25/1492 & $\mathrm{TI} / \mathrm{EC}$ & White & Cristobalite, anatase, a-quartz & $\mathrm{Ti}$ & $638,517,396,144$ \\
\hline MMA 1994.35.13 & Colonial & White & Cerussite, hydrocerussite & $\mathrm{Pb}$ & NA \\
\hline MMA 1994.35.17 & Colonial & White & Cerussite, hydrocerussite & $\mathrm{Pb}$ & NA \\
\hline MMA 1994.35 .26 & Colonial & White & Cerussite, hydrocerussite & $\mathrm{Pb}$ & NA \\
\hline Private collection 3 & Colonial & White & Cerussite, hydrocerussite & $\mathrm{Pb}$ & NA \\
\hline
\end{tabular}

TI/EC Transitional Inka/Early Colonial, $W$ weak peak, NA not analyzed

and XRF results and are broadly consistent with those obtained from reference samples of Elaeagia resin, reinforcing earlier findings that the presence of this resin is characteristic of polychromed colonial qeros [8]. We also add that the spectrum of white pigment from an eighth qero (NMAI 06/5837), stylistically belonging to the later colonial period but not included in Table 1 , which XRF had shown to contain $\mathrm{Pb}$ but no $\mathrm{Ti}$ or $\mathrm{Si}$, bears a peak at 


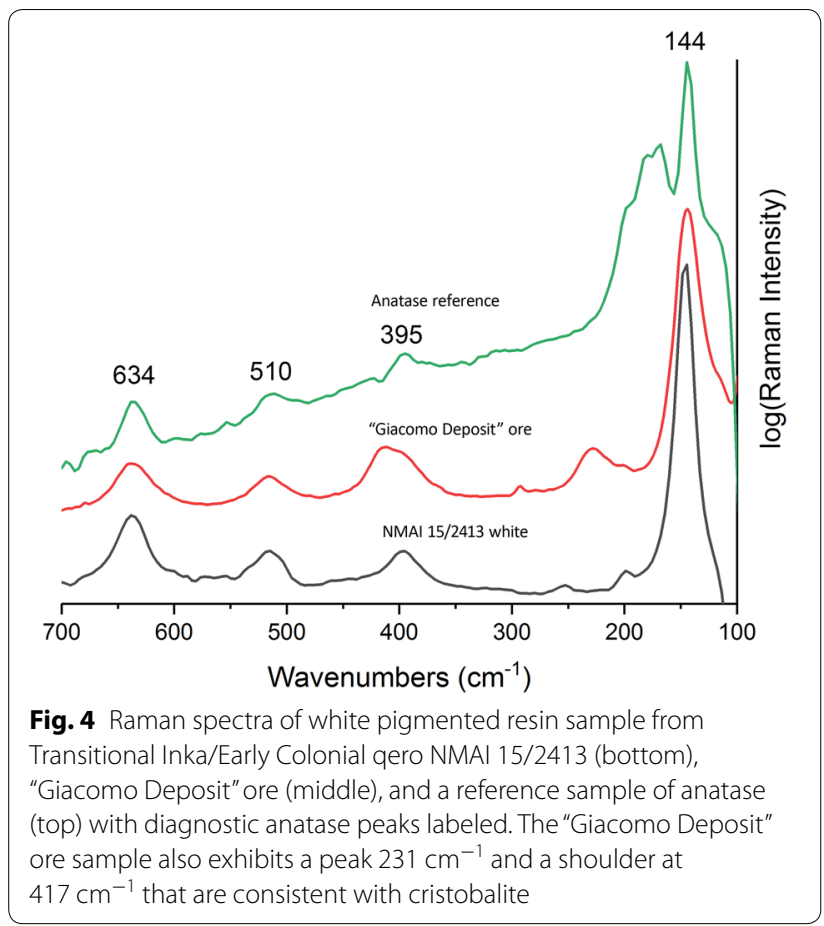

$1052 \mathrm{~cm}^{-1}$ consistent with lead carbonate, but no features characteristic of anatase.

\section{SEM/EDS}

Secondary electron images of the sample of white pigment from MMA 1994.35.12 show clusters of what appear to be anhedral grains with heterogeneous morphology (Fig. 5). The indistinct and rounded boundaries of the grains and clusters suggest the presence of significant amounts of binding medium. This is not surprising in view of the highly intractable solubility of aged Elaeagia resin in nearly all organic solvents and the constraints imposed on the pre-treatment of our sample by its extremely small size. SEM images suggest two size distributions for the grains. Grains in the larger set tend to be coarse particles, a very few with tabular morphology, having average diameters between 10 and $100 \mu \mathrm{m}$. Associated with these particles is a subset of smaller pellets and platelets with average diameters less than $5 \mu \mathrm{m}$.

EDS analysis of the grain surfaces examined in the SEM shows them generally to be rich in Si with local concentrations of $\mathrm{Ti}$ often associated with the smaller pellets (Fig. 5). Occasional larger tabular grains show significant $\mathrm{Al}$ and $\mathrm{Ca}$. In conjunction with the XRD data, we interpret the high-Si grains to likely be cristobalite and/or $\alpha$-quartz, the high-Ti grains most likely as anatase possibly mixed with rutile, and the tabular grains with $\mathrm{Al}, \mathrm{Ca}$ and Si plausibly as plagioclase feldspar.

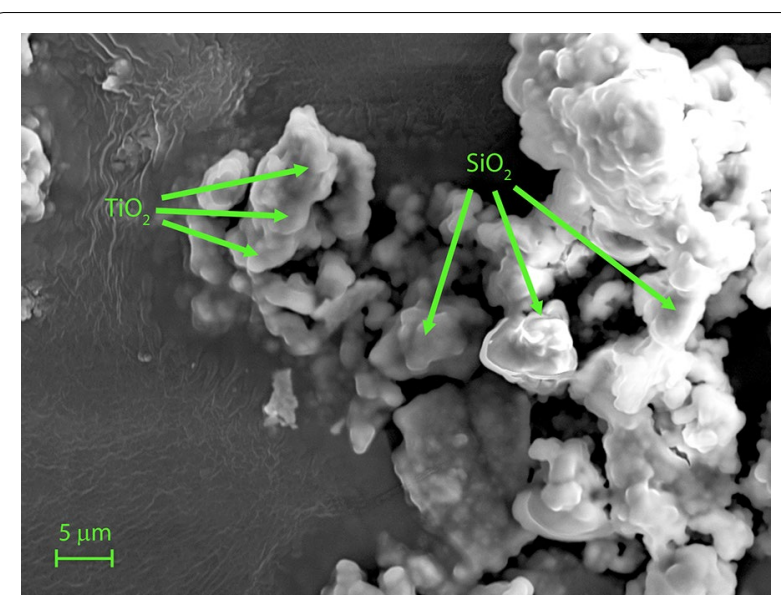

Fig. 5 Secondary electron image of sample of white pigment from Transitional Inka/Early Colonial qero, MMA 1994.35.12. EDS analysis suggests silica particles and titanium dioxide pellets as indicated

\section{Radiocarbon age determinations}

Radiocarbon ages and their corresponding calibrated calendar ages for the wood samples taken from the two qeros referenced above are shown in Table 3 as reported by the NSF-Arizona AMS Laboratory. The calendar-age ranges shown are the 2-sigma ranges derived from the reported radiocarbon ages as determined using the calibration program CALIB (rev. 7.0.4), by M. Stuiver and P. J. Reimer [34]. This program uses the IntCal104 data set [35]. While the determination for the sample from MMA 1994.35.12 (Fig. 6) yields an apparent bimodal distribution of calendar ages, the small separation of the two subranges permits an assignment in the fourteenth century to be made with reasonable confidence. For the other sample from MMA 1994.35.14 (Fig. 7), more than 98\% of the distribution falls approximately in the first half of the fifteenth century. It should be emphasized that the ages reported are for the wood and should be interpreted with the usual cautionary allowance for possible use in qero production, either as deceased historical raw material or as early portions of long-lived, slow-growing trees.

\section{Possible sources}

In morphology and context, the titanium dioxide/silica white pigment appears to be a naturally occurring-albeit uncommon-mineral assemblage. On this premise, our search for a plausible geological source has been guided by conditions that would favor the observed mineralogy and at the same time offer ease of access and recognition, as well as adequate supply in a geographic area near that of the associated qero production. These constraints have suggested candidates that include pedogenic soils known as silcretes that typically occur as 
Table 3 Radiocarbon ages and calibrated calendar ages for wood samples taken from two qeros

\begin{tabular}{lllll}
\hline Qero & Lab sample ID & $\boldsymbol{\delta}^{\mathbf{1 3}} \mathbf{C}$ & Radiocarbon age $( \pm \mathbf{1} \boldsymbol{\sigma})$ & $\mathbf{2 \sigma}$ calendar ages and relative areas \\
\hline MMA 1994.35.12 & AA90151 & -22.9 & $643 \pm 34$ years BP & $1281-1330$ AD [0.44]; 1338-1397 AD [0.56] \\
MMA 1994.35.14 & AA90150 & -23.1 & $492 \pm 34$ years BP & $1330-1338$ AD [0.01]; 1397-1453 AD [0.99] \\
\hline
\end{tabular}

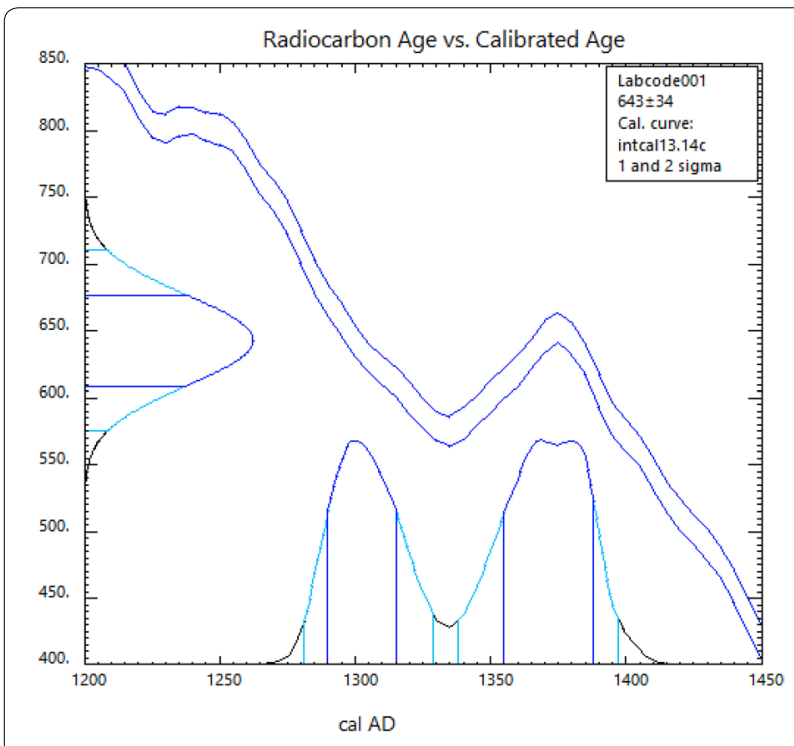

Fig. 6 Radiocarbon age vs. calendar age for wood sample from Transitional Inka/Early Colonial qero, MMA 1994.35.12. Plot derived using the calibration program, CALIB (rev. 7.0.4), by M. Stuiver and P. J. Reimer (copyright 1986-2017), available online as freeware at http:// calib.org [28]. The bi-modal distribution suggests a date within the fourteenth century to be assigned with reasonable confidence

surficial deposits in areas subject to desertification, such as the Atacama Desert of northern Chile and southern Peru, as well as syngenetic and epigenetic deposits associated with volcanic exposures such as might occur throughout the Andes. Among the latter candidates, we learned of one said to have been discovered in 1998 and that was offered for exploitation on a commercial scale as a titanium ore body in southern Peru. Referred to as the "Giacomo Deposit", its location was described at the time as being in the district of Estique, Tarata province, approximately $60 \mathrm{~km}$ northeast of the city of Tacna, on the western foothills of the Barroso Cordillera [31]. Local map coordinates published elsewhere indicate that the deposit is located a few kilometers southwest of an epithermal gold mining claim known as the Baños del Indio $[36,37]$. The photographs published online suggest the deposit to be a lenticular outcrop bounded by layered rock and conspicuous for its large scale, surface exposure, and white coloration. Oxide analyses given for samples of the ore show the principal components to be $\mathrm{SiO}_{2}$ and $\mathrm{TiO}_{2}$ in varying proportions and accounting together for more than $90 \%$ of the composition, possibly suggesting an unusual hydrothermal alteration for its formation [31-33]. While we sought to verify this occurrence and gain an understanding of its physical and geochemical origin by on-site inspection, security restrictions by the individuals claiming rights to the deposit rendered unsuccessful an attempt by one of us (EK) to visit the site in 2011. We emphasize that, beyond the information available from the online sources, we have no direct evidence for this occurrence or the conditions of its formation. Samples of what was said to be the unprocessed ore were obtained from the concession owner, Millennium Inorganic Chemicals, Inc. (now part of Cristal Corporation) and were analyzed by XRF, XRD, Raman and SEM/EDS. The results of these analyses closely resemble those obtained from the qero pigment samples and show this ore to be predominantly a mixture of cristobalite, anatase, and $\alpha$-quartz-with minor amounts of rutilein relative proportions comparable to those observed in the qero samples. The Raman spectrum of a "Giacomo Deposit" ore sample shows a clear anatase signature and additional features at 417 and $231 \mathrm{~cm}^{-1}$ that are consistent with cristobalite (Fig. 4) [38]. The XRD pattern acquired from a sample of the ore body is shown in Fig. 8 together with the patterns obtained from the three qeros referenced in Fig. 3. The somewhat broader lines associated with the qero samples may reflect a finer particle size as might be expected for a ground pigment, as well as the lower resolution of the area detector used for the microdiffraction analyses of the qero pigments relative to the diffractometer used for the analysis of the ore. Synthetic mixtures of the above four principal phases were prepared and analyzed by X-ray diffraction under the same conditions used for the analysis of the ore. The closest match in overall pattern intensity was obtained with a mixture consisting of approximately $73 \mathrm{wt} \%$ cristobalite, $13 \mathrm{wt} \%$ anatase, $9 \mathrm{wt} \% \alpha$-quartz, and $5 \mathrm{wt} \%$ rutile. We note that the metastable persistence of both cristobalite and anatase at ambient temperatures has been shown to involve many factors, but principally the high activation energies required for the reconstructive transformations of cristobalite to $\alpha$-quartz and of anatase to rutile [39].

\section{Discussion}

The identification of a naturally occurring white pigment based on cristobalite and anatase is noteworthy. While there have been other claims of original titanium dioxide-bearing white pigments on ancient objects, these 


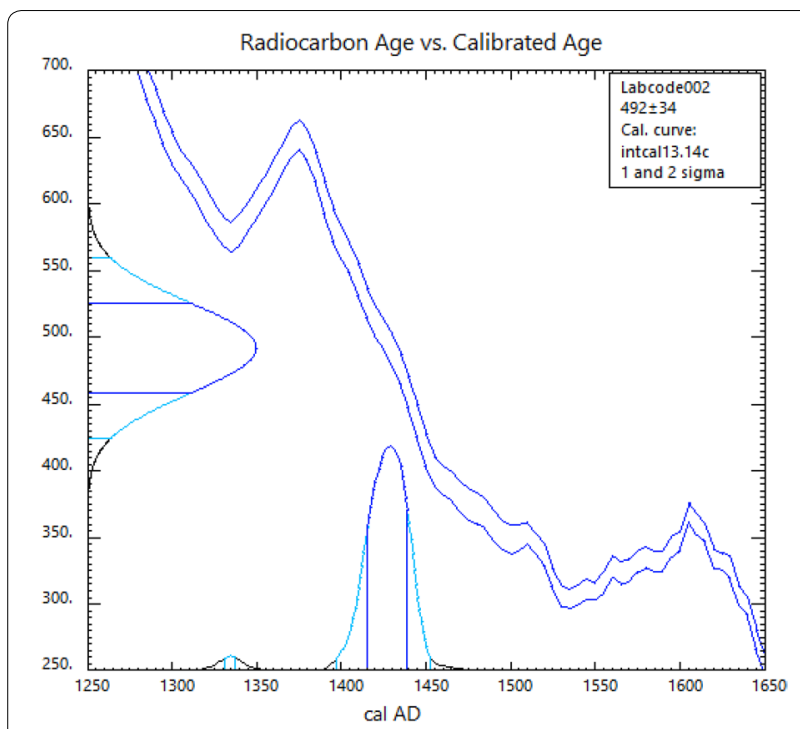

Fig. 7 Radiocarbon age vs. calendar age for wood sample from Transitional Inka/Early Colonial qero, MMA 1994.35.14. Plot derived using the calibration program, CALIB (rev. 7.0.4), by M. Stuiver and P. J. Reimer (copyright 1986-2017), available online as freeware at http:// calib.org [28]. The distribution suggests a date in the first half of the fifteenth century to be assigned with reasonable confidence

claims have often been based on Raman analysis alone and have subsequently been argued to suffer from the disproportionate response of this method to the typical small amounts of rutile and anatase in what are likely to have been clay-based materials [40-43]. In the present case, however, the Raman results corroborate the findings of the other analytical techniques, providing evidence of the use of cristobalite containing a significant, if lesser, amount of natural anatase, possibly from an ore body such as the "Giacomo Deposit". Indeed, the strong light scattering properties, and hence remarkable tinting strength, of titanium dioxide pigments would allow practical use of a source material such as the "Giacomo Deposit" ore with what the XRD results suggest is a lower proportion of anatase relative to cristobalite [44]. Furthermore, extensive examination of the qeros decorated with pigmented inlay confers a high level of confidence in the originality of these occurrences. It has often been suggested that anatase would not be expected to be found in artwork created before 1920, as the pigment was first synthesized and produced on a commercial scale in 1916-1918 [45]. On this basis, the presence of synthetic anatase in a work claiming pre-twentieth century origin has sometimes been interpreted as an indication of forgery, the most extensive discussion of which having been in the context of the Vinland Map [46-48]. However, based on the context of occurrence, the anatase found on the qeros in this study appears to be of natural origin and original to the vessels.

The data reported here support chronologies based on iconography and style proposed by other researchers [2,

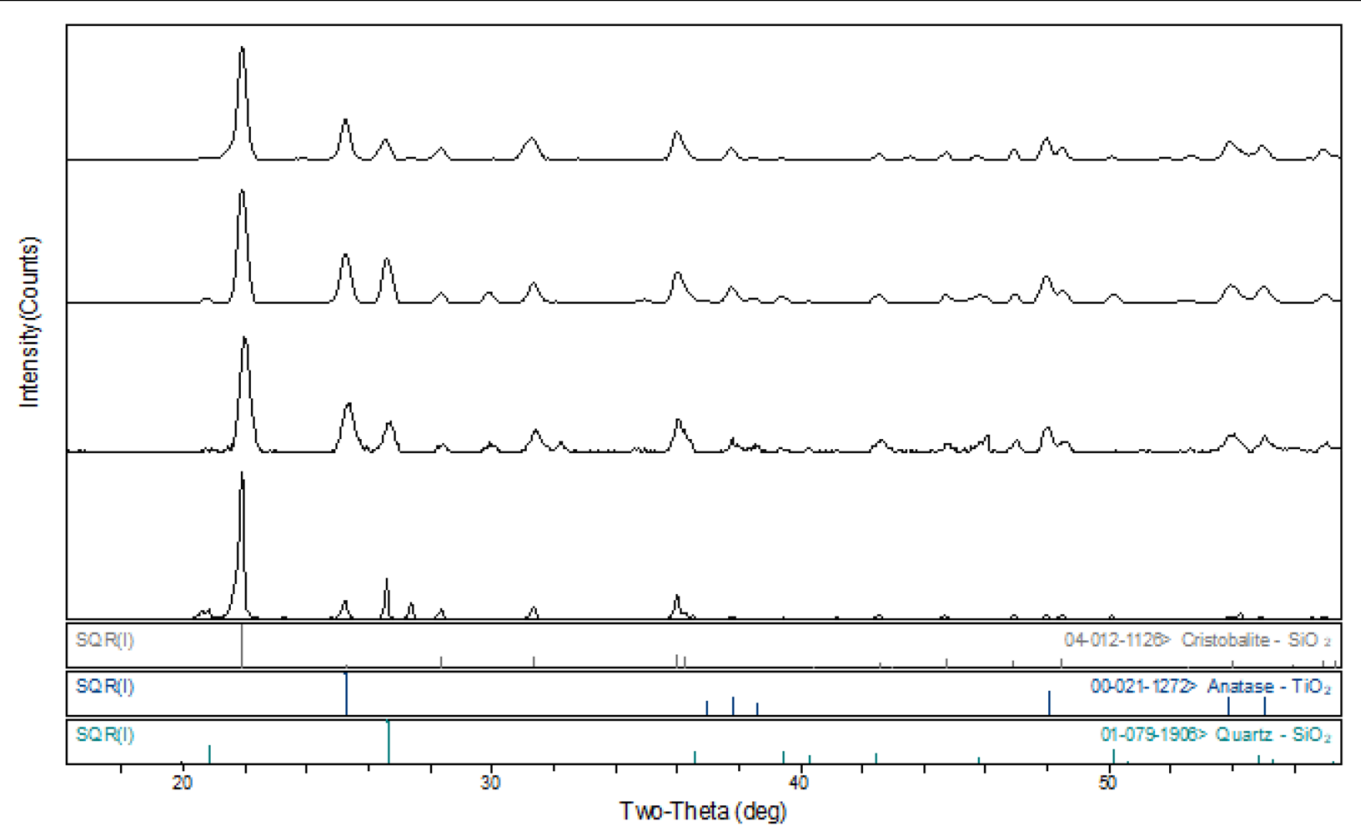

Fig. 8 XRD patterns of white pigments from the three Transitional Inka/Early Colonial qeros referenced in Fig. 3 together with the pattern obtained from the "Giacomo Deposit" ore (top: Museo Inka 230; upper middle: NMAI 20/0236; lower middle: AMNH B1847; bottom: "Giacomo Deposit" mine ore). Ribbon bar intensities of PDF patterns shown as square root of relative value for legibility 
3]. Our findings suggest that the titanium dioxide/silica white pigment was used only during the Transitional Inka/Early Colonial period with perhaps an earlier history, and was subsequently replaced by lead carbonate whites, probably with some overlap or concurrence in production and style. While Inka qeros have previously been understood to be decorated without the application of color, the two vessels made from wood with AMS radiocarbon dates from the Inka period or earlier both display polychromy. Again, while these dates may reflect the use of either deceased raw material or early portions of slow-growing, long-lived trees as previously noted, the occurrence of a titanium dioxide/silica pigment on the excavated qero from the securely dated tomb at Ollantaytambo supports an assigned early date for use of this pigment. Identification of the binder from the Ollantaytambo qero as the resin from the plant genus Elaeagia, found to be the diagnostic binding material for qeros decorated with this polychrome technique, suggests that the pigment-binder combination identified has its roots in the Inka period with persistence into the Transitional Inka/Early Colonial and later colonial periods [10]. Recent work demonstrates that species of Elaeagia can be distinguished chemically with possible implications for time and place of production [8]. Although this resin has been used historically and in modern times in the Pasto region of Colombia, direct evidence of its use during the Inka period awaits discovery, as there are no qeros or other objects known to the authors that have been definitively dated to that period and on which the resin has been found $[8,49-51]$. While the number of extant qeros thus far identified as decorated with the titanium dioxide/silica pigment is relatively small-approximately $8 \%$ of the qeros examined in the larger study-this is perhaps not surprising given that many of these qeros were likely destroyed during Spanish campaigns of extirpation. During this time, qeros and other indigenous objects or imagery deemed idolatrous were singled out for destruction [2].

Not unexpectedly, there are no known records of the procurement, processing, or transport of this titaniferous white pigment that would indicate its importance to the Inka or its probable source in the southern Andes. Ethnohistorical documents, such as the chronicles of Betanzos, Cobo, and Guaman Poma, occasionally include discussion of the materials and technologies of Inka art and architecture, but make no mention of this material as a pigment. Further investigations into Pre-Columbian white pigments, especially in the southern Andes, may well reveal its use in other ancient or historic contexts, but at present there is no evidence of its use except on polychromed qeros of the Transitional Inka/Early Colonial period discussed here. Confirmation of the "Giacomo
Deposit" or a related proximate occurrence must await on-site structural analysis and geochemical study. For our present work, its provisional acceptance as a plausible source of the titanium dioxide/silica pigment is based on its visual appearance, scale, and geographic location in the region of Tacna in southern Peru, as reported online. Colonized by the Tiwanaku state and later by the Inka empire, this region was the northernmost point of the Inka Empire's southern realm known as Collasuyu, an area that incorporated much of what is now Bolivia, northwest Argentina, and northern Chile. This region, traversed by a network of imperial roads linking the highlands to the coast and connecting administrative centers and settlements, was heavily exploited by the Inka (and later the Spanish) for its rich mineral resources [52].

Long-distance transport of raw materials throughout the Andes was carried out for millennia and, although altered by Spanish rule, movement of materials persisted into the colonial period. Although the source for this titanium dioxide/silica pigment is not documented historically to our knowledge, the "Giacomo Deposit" ore body offers a plausible local candidate. Furthermore, for an exposure of this size, the geological environment may well have remained sufficiently intact on the historical time-scale as to allow the argument that such an ore body was as conspicuous in the sixteenth century as it is today.

\section{Conclusions}

This study has identified a white pigment based on titanium dioxide and silica on twelve wooden qeros, two of which yield AMS radiocarbon dates corresponding to the Inka period or before, while a third was excavated from a site dated to 1536-1537 CE, at the time of first contact between the Inka and Spanish. A possible source for this pigment may exist in southern Peru at a site reportedly known as the "Giacomo Deposit". The discovery of a white pigment based on titanium dioxide and silica is remarkable on several accounts: in addition to being the only known reported instance of the intentional use of a $\mathrm{TiO}_{2}$-rich material as a pigment in this area, it provides important information about the technology of early qero production, supporting iconographic and stylistic marker chronologies proposed by other researchers [2, 3]. The evidence reported here suggests that the titanium dioxide/silica white pigment was used during the Transitional Inka/Early Colonial period (ca. 1532-1570) and was subsequently replaced by lead carbonate whites, probably with some overlap or concurrence in production and style. The AMS radiocarbon ages obtained for the wood from two qeros in the group studied here reinforce this dating and show that, while Inka qeros have previously been understood to be decorated without the application of color, 
the wood on these two examples likely dates from the Inka period (1475-1532). The presence of this titanium dioxide/silica pigment on the excavated qero from the securely dated tomb at Ollantaytambo further suggests that the use of this pigment during the early colonial period may well represent a continuation of practice from Inka times. Our assertion that this pigment is original is supported by its geochemical signature, its exclusive occurrence on the excavated Ollantaytambo qero and the eleven other qeros stylistically attributed to the Transitional Inka/Early Colonial period, and by its consistent association with Elaeagia resin, the diagnostic binding material for all qeros decorated with this polychrome technique.

\section{Additional files}

Additional file 1. Images of the 16 geros in this study as shown in Tables 1 and 2

Additional file 2 . Selected listings of $X R D$ results.

Additional file 3. Raman spectra of white pigments.

\section{Authors' contributions}

$E K, E H, E P$ and JL contributed the cultural and art historical background. RN, JHF and OM performed XRD, XRF and Raman analyses and interpretation of data. EK contributed portable XRF analyses from NMAI and obtained samples and images from the Museo Inka qero. All authors were involved in drafting the manuscript. All authors read and approved the final manuscript.

\begin{abstract}
Author details
${ }^{1}$ Metropolitan Museum of Art, 1000 Fifth Avenue, New York, NY 10028, USA. ${ }^{2}$ Smithsonian National Museum of the American Indian, Cultural Resources Center, 4220 Silver Hill Road, Suitland, MD 20746, USA. ${ }^{3}$ Scientific Research Lab, Museum of Fine Arts, 465 Huntington Avenue, Boston, MA 02115, USA. ${ }^{4}$ University of California Los Angeles, A410 Fowler Building, Los Angeles, CA 90095-1510, USA. ${ }^{5}$ American Museum of Natural History, 79th Street and Central Park West, New York, NY 10024, USA. ${ }^{6}$ Smithsonian Museum Conservation Institute, 4210 Silver Hill Road, Suitland, MD 20746, USA.
\end{abstract}

\section{Acknowledgements}

We are grateful to Jorge Flores Ochoa and Antonia Miranda at the Museo Inka, Cuzco, for granting permission to examine, sample, and photograph the Ollantaytambo gero and to a private collector, Michael Kasser, for permission to sample his objects. We thank Paul Powhat at the Mineralogy Department of the Smithsonian National Museum of Natural History for supplying reference samples of anatase, rutile and brookite. We are also grateful to Federico Carò, Associate Research Scientist in the Department of Scientific Research at The Metropolitan Museum of Art for SEM imaging and EDS analyses. We thank Millennium Inorganic Chemicals, Inc. (now part of Cristal Corp.) for samples of the "Giacomo Deposit" ore body. We thank Ed Vicenzi at the Smithsonian Museum Conservation Institute for his early contributions to this study. We are deeply grateful to Abelardo Sandoval for his assistance in our attempts to locate pigment sources in Peru.

\section{Competing interests}

The authors declare that they have no competing interests.

\section{Availability of data and materials}

On request, the authors will gladly share other additional files and data not published in the article.

\section{Funding}

The Andrew W. Mellon Foundation funded a curatorial/conservation research collaboration at the Brooklyn Museum that supported the original analyses performed at the Museum of Fine Arts in Boston.

\section{Publisher's Note}

Springer Nature remains neutral with regard to jurisdictional claims in published maps and institutional affiliations.

Received: 20 February 2018 Accepted: 22 June 2018

Published online: 01 July 2018

\section{References}

1. Allen CJ. The Incas have gone inside: pattern and persistence in Andean iconography. Res Anthropol Aesthetics. 2002:42:180-203.

2. Cummins TBF. Toasts with the Inca: Andean abstraction and colonial images on quero vessels. Ann Arbor: University of Michigan Press; 2002.

3. Rowe JH. The Chronology of Inca Wooden Cups. In: Lothrop SK, editor. Essays in pre-columbian art and archaeology. Cambridge: Harvard University Press; 1961. p. 317-41.

4. Betanzos J de. Narrative of the Incas (1557). In: Hamilton R, Buchanan D, translators and editors. Austin: University of Texas Press; 1996.

5. Guamán Poma de Ayala F. Nueva crónica y buen gobierno. Madrid: Historia; 1987. p. 16.

6. Cobo B. History of the Inca Empire. In: Historia del Nuevo Mundo (1653). Hamilton, R, editor and translator. Austin: University of Texas Press; 1983.

7. Martinez CJL. El virrey Toledo y el control de las voces andinas colonials. Colonial Latin Am Rev. 2012;21 (2):175-208.

8. Newman R, Kaplan E, Derrick M. Mopa mopa: scientific analysis and history of an unusual South American resin used by the Inka and artisans in Pasto, Colombia. J Am Instit Conserv. 2015;54(3):123-48.

9. Kaplan E, Pearlstein E, Howe E, Levinson J. Análisis técnico de qeros pintados de los Periodos Inka y Colonial. In: Iconos: Revista peruana de conservación, arte y arqueología. 1999, p. 30-38.

10. Newman R, Derrick M. Painted qero cups from the Inka and Colonial periods in Peru: an analytical study of pigments and media. In: Vandiver P, Goodway M, Mass J, editors. Materials issues in art and archaeology 6, materials research society proceedings. 2002;712:291-302.

11. Duviols P. Un inédit de Cristóbal de Albornoz: La instruccíon para descubrir todas las guacas del Pirú sus camayos y haziendas (ca. 1582). J Société des Américanistes. 1967;56(1):7-39.

12. Álvarez B, DelPino F. De las costumbres y conversión de los indios del Perú: Memorial a Felipe II; (1588). In: del Rubio MC, Robles JJRV, del Díaz FP, editors. Crónicas y Memorias, vol. 4. Madrid: Polifemo; 1998.

13. de Avila F. Tratado de los evangelios que nuestra madre la Iglesia propone en todo el año desde la primera domínica de adviento hasta la última misa de difuntos, santos de España y añadidos en el nuevo rezado. Lima: Jerónimo de Contreras; 1646-1648.

14. de Toledo F. Libro de la visita general del Virrey Toledo (1570-75). Revista Histórica, Organo del Instituto Histórico del Perú. 1924;7(2):114-216.

15. Llanos LA. Informe sobre Ollantaytambo, Lima. Revista del Museo Nacional. 1936;5(2):123-56.

16. Kaplan E, Howe E, Pearlstein E, Levinson J. The qero project: conservation and science collaboration over time. In: Research and technical studies postprints, American Institute for Conservation 2012;3: p. 1-24. http:// www.conservation-us.org/resources/our-publications/specialty-group/ research-and-technical-studies. Accessed 24 May 2018.

17. Pearlstein E, Kaplan E, Howe E, Levinson J. Technical analyses of Inka and colonial painted wooden keros. AlC Objects Special Group Postprints. 1999:6:94-111.

18. Howe E. Color and resin on andean qeros. Met Object. 2001;3:4-6.

19. Ochoa JAF, Arce EK, Argumedo RS. Qeros: arte Inka en vasos ceremonials. Lima: Banco de Crédito del Perú; 1998.

20. Cooke CA, Abbott MB, Wolfe AP. Metallurgy in southern South America. In: Seline H, editor. Encyclopedia of the history of science, technology, and medicine in non-western cultures. Dordrecht: Kluwer Science; 2008. p. 1658-62. 
21. Fester GA, Cruellas J. Colorantes de Paracas, Lima. Revista del Museo Nacional. 1934;3(1-2):154-6.

22. Petersen G. Mining and metallurgy in ancient Peru: a translation of Minería y Metalurgia en el Antíguo Perú (1970). In: Brooks W, translator. The Geological Society of America; Special Paper 467. Boulder; 2010.

23. Siracusano G. Pigments and power in the Andes: from the material to the symbolic in Andean cultural practices, 1500-1800. Barnett I, translator. London: Archetype Publications Ltd; 2011.

24. Vaughn KJ, Conlee C, Neff H, Schreiber K. A compositional analysis of Nasca pigments: Implications for craft production on the Prehispanic south coast of Peru. In: Speakman RJ, Neff H, editors. Laser Ablation ICPMS: a new frontier in archaeological characterization studies. Albuquerque: University of New Mexico Press; 2005. p. 138-54.

25. Freire E, Acevedo V, Halac EB, Polla G, López M, Reinoso M. X-ray diffraction and Raman spectroscopy study of white decorations on tricolored ceramics from Northwestern Argentina. Spectrochim Acta Part A Mol Biomol Spectrosc. 2016;157:182-5.

26. Wright V, Pacheco G, Torres H, Huaman O, Watanave A, ZeballosVelasquez EL, Suchomel MR, Suescun L, Moulin C, Sandoval PCM. Mural paintings in Ancient Peru: the case of Tambo Colorado, Pisco Valley. Sci Technol Archaeol Res. 2016;1(2):11-21. https://doi.org/10.1080/20548 923.2015.1133118.

27. Brooks WE, Piminchumo V, Suárez H, Jackson JC, McGeehin JP. Mineral pigments at Huaca Tacaynamo (Chan Chan, Peru). Bulletin de I'Institut français d'études andines. 2008;37(3):441-50.

28. Scott DA, Doughty DH, Donnan CB. Moche wallpainting pigments from La Mina, Jequetepeque, Peru. Stud Conserv. 1998:43:177-82.

29. Osorio F, Díaz Fleming G, Martinez U, Campos-Vallette MM, Clavijo E, Aliaga AE, Fernanda Espinosa M, Bracchitta D. Micro-Raman spectroscopy of decorated pottery of the Diaguita culture from IV Region, Chile (9th15th century AD). J Child Chem Soc. 2014:59(3):2619-21.

30. Dinator MI, Morales JR. Characterization of colour pigments in preColumbian Chilean potteries by PIXE elemental analysis. J Radioanal Nucl Chem. 1990;140(1):133-9.

31. Giacomo Deposit General Report 2009. https://www.slideshare.net/ omarmauricior/giacomo-deposit-report. Accessed 24 May 2018.

32. Zhou L, Messer T, Wen F-C, Banash M. TiO2 compounds obtained from a high silica content ore. US Patent 6,713,038; 2004a, b. https://paten ts.google.com/patent/US20020000138. Accessed 24 May 2018.

33. Staikova D. Titanium Mine - Giacomo Deposit Peru, City of Tacna—for sale. 2015. https://www.youtube.com/watch?v=x_SulEldZFo. Accessed 24 May 2018

34. Stuiver M, Reimer PJ, Reimer RW. CALIB 7.1. 2017. http://calib.org. Accessed 24 May 2018.

35. Reimer PJ, Baillie MG, Bard E, Bayliss A, Beck JW, Bertrand CJ, Blackwell $P G$, Buck CE, Burr GS, Cutler KB, et al. IntCal04 terrestrial radiocarbon age calibration, 0-26 cal kyr BP. Radiocarbon. 2004;46(3):1029-58.
36. Bedoya, GT, Chavez RR, Lince ML, Garcia EP, Zegarra GF. Zonificación Ecológica y Económica-Región Tacna: Estudio Geología y Geomorfología. Publication of Gobierno Regional Tacna; 2007. http://geoservido rperu.minam.gob.pe/geoservidor/Archivos/Mapa/Tacna/Memoria_Descr iptiva_Geologia.pdf. Accessed 24 May 2018.

37. Dufresne MB, Bahrami B. Technical report for the Huilacollo Project, Tacna Province, Southern Peru. Prepared by APEX Geoscience Ltd for Auryn Resources Inc. Edmonton; 2017. https://www.aurynresources.com/site/ assets/files/2225/auryn_-_huilacollo_ni_43-101__oct10_2017_final.pdf. Accessed 24 May 2018

38. Lafuente B, Downs RT, Yang H, Stone N. The power of databases: the RRUFF project. In: Armbruster T, Danisi RM, editors. Highlights in mineralogical crystallography. Berlin: De Gruyter; 2015. p. 1-30.

39. Hanaor DAH, Sorrell CC. Review of the anatase to rutile phase transformation. J Mater Sci. 2011;46:855-74.

40. Clark RJH, Correia A, Wang Q. Can the Raman spectrum of anatase in artwork and archaeology be used for dating purposes? Identification by Raman microscopy of anatase in decorative coatings on Neolithic (Yangshao) pottery from Henan, China. J Archaeol Sci. 2007;34:1787-93.

41. Edwards HGM, Hassan NFN, Middleton PS. Anatase-a pigment in ancient artwork or a modern usurper? Anal Bioanal Chem. 2006;384:1356-65.

42. Middleton AP, Edwards HGM, Middleton PS, Ambers J. Identification of anatase in archaeological materials by Raman spectroscopy: implications and interpretation. J Raman Spectrosc. 2005;36:984-7.

43. Murad E. Identification of minor amounts of anatase in kaolins by Raman spectroscopy. Am Miner. 1997:82:203-6.

44. Braun JH, Baidins A, Marganski RE. TiO2 pigment technology: a review. Prog Org Coat. 1992;20(2):105-38.

45. Laver M. Titanium dioxide whites. In: Fitzhugh EW, editor. Artists' pigments, a handbook of their history and characteristics, vol. 3. Oxford: Oxford University Press; 1997. p. 295-355.

46. McCrone WC. The Vinland Map. Anal Chem. 1988;60:1009-18.

47. Harbottle G. The Vinland Map: a critical review of archaeometric research on its authenticity. Archaeometry. 2008;50(1):177-89.

48. Towe KM, Clark RJH, Seaver KA. Analysing the Vinland Map: a critical review of a critical review. Archaeometry. 2008;50(5):887-93.

49. Botina JR. El barniz o mopa-mopa, Elaeagia pastoensis Mora (Rubiaceae): estado actual de su conocimiento en Colombia. Mocoa: Corporación Autónoma Regional del Putumayo; 1990.

50. Mora-Osejo LE. El barniz de Pasto. Caldasia. 1977;11:5-31.

51. Stuckart JM. Barniz de Pasto: The impact of Tourism on a Traditional Craft. PhD dissertation. Pittsburgh: University of Pittsburgh;1982.

52. D'Altroy TN, Williams V, Lorandi AM. The Inkas in the Southlands. In: Burger $\mathrm{RL}$, editor. Variations in the expression of Inka power. Washington, DC: Dumbarton Oaks; 2007. p. 88-135.

\section{Submit your manuscript to a SpringerOpen ${ }^{\circ}$ journal and benefit from:}

- Convenient online submission

- Rigorous peer review

- Open access: articles freely available online

- High visibility within the field

Retaining the copyright to your article

Submit your next manuscript at springeropen.com 